\title{
Impact of community pharmacy-based asthma education program on the patients' clinical and humanistic outcomes.
}

\author{
Ofor Amala C \\ Department of Clinical pharmacy and Biopharmaceutics \\ Faculty of pharmaceutical sciences, \\ Enugu State University of Science and Technology, \\ Agbani, Enugu State. \\ Phone number: +2348037403512 \\ Email: ofachcurepharm@gmail.com \\ Nduka Sunday O \\ Department of Clinical pharmacy and pharmacy management \\ Faculty of pharmaceutical sciences, \\ Nnamdi Azikiwe University, \\ Agulu campus, Anambra State, Nigeria.
}

\author{
Ukwe Chinwe V \\ Department of Clinical pharmacy and pharmacy management, \\ Faculty of pharmaceutical sciences, \\ University of Nigeria, \\ Nsukka, Enugu, Nigeria.
}

DOI: $10.31364 / \mathrm{SCIRJ} / \mathrm{v} 8 . i 3.2020 . P 0320752$

http://dx.doi.org/10.31364/SCIRJ/v8.i3.2020.P0320752

\begin{abstract}
Asthma illness is a global burden in terms of the extent and durability. There are many indications in Nigeria that asthma is under-diagnosed, under-treated, and uncontrolled in a substantial proportion of the population. Community pharmacists are regarded as the most accessible healthcare professionals and in a viable position to providing services to asthma patients but are often inconsistent and underutilized in its management. This study aimed at evaluating the impact of community pharmacy-based asthma education program on the patients' clinical and humanistic outcomes. An intervention study was carried out in a registered community pharmacy in Anambra state of Nigeria among adult asthma patients from 18 years old using a one group pre-posttest design between February 2018 and May 2018. Patients recruited for the study initially filled pre-test questionnaire on asthma knowledge, asthma-related quality of life, perceived control of asthma, subjects' adherence to medication use, and inhaler technique before a two-day educational intervention was given to each subject. Thereafter, a post-test questionnaire that has similar content with the pre-test questionnaire was given. Data was collected and analyzed using SPSS version 23. Descriptive statistics were computed for the data of the respondents and Mcnemar test was used to test the statistical difference between the pre-test and post-test scores of each measuring tool. P values $<0.05$ were considered to be significant. Among the 21 subjects who completed the study, there was significant improvements in subjects' knowledge of asthma $(\mathrm{P}<0.01)$, inhaler technique use $(\mathrm{P}<0.01)$, subjects' adherence to medication ( $\mathrm{P}<0.01)$, asthma-related quality of life $(\mathrm{P}<0.01)$, and subjects' perceived control of asthma $(\mathrm{P}<0.01)$, after the educational intervention. The study demonstrated that the community pharmacist's educational intervention improved the subjects' clinical (inhaler technique, subjects' adherence) and humanistic (asthma-related quality of life, perceived control of asthma, asthma knowledge) outcomes.
\end{abstract}

Keywords - Asthma education, community pharmacy, patients, clinical, humanistic, outcomes. 


\section{Introduction}

Asthma patients' education is a vital tool that can enhance the patients' knowledge and attitude to asthma management, thereby aids in improving the treatment outcomes. This education is paramount in reducing the global burden of asthma disease which is estimated to affect as much as 334 million people of all ages worldwide ${ }^{(17)}$, with Nigeria alone having about 15 million current asthma sufferers of all ages ${ }^{(10)}$. A study conducted to determine the estimate of asthma prevalence in Africa in 1990, 2000, and 2010 showed; about 34.1 million asthma cases (in 1990), about 43.1 million cases (in 2000) and about 119.3 million cases (in 2010) ${ }^{\text {(1) }}$. While the prevalence seems worrisome, a postulate of Nigeria likely to have as many as 100 million asthma sufferers in $2025^{(10)}$ seems to place Nigeria as a country that needs urgent asthma intervention. Non-compliance ${ }^{(7)}$, improper inhaler technique ${ }^{(2,20)}$, and inadequate asthma education ${ }^{(3)}$ are some of the factors associated with poor asthma treatment outcomes in various studies; while several other studies conducted outside Nigeria have shown that pharmacists in dedicated asthma care/education program can influence outcomes $(5,15,24)$. The Nigeria community pharmacists who always come in contact with asthma patients are sitting on a gold mine as far as the implementation of asthma care program services is concerned, but are often inconsistent and underutilized. No previous study on asthma education is known to have been conducted in the community pharmacies in Nigeria. Hence, this study was designed to determine the impact of community pharmacy-based education program on patients' clinical and humanistic outcomes in a community pharmacy in Anambra State, South Eastern part of Nigeria. The study specifically evaluated the patients' knowledge of asthma, ability to adhere to medication use, asthma-related quality of life, perceived control of asthma, and correct use of inhaler technique.

\section{Method}

\section{Study setting and area}

The study was conducted in a conveniently selected registered community pharmacy in Abagana, Anambra State, South East of Nigeria between February 2018 and May 2018; considering its' location that connects to three villages, the average daily size of 70 90 clientele, the private consulting room which was separated from the dispensary, and the staff strength which included two pharmacists (a superintendent pharmacist and a locum pharmacist), two nurses, one pharmacy technician, two cashiers. Abagana town is one of the semi-urban areas in the state and lies approximately 13 kilometers away from the State capital and about 20 kilometers away from the commercial city centre of the state through Enugu-Onitsha old road. It is the headquarter of Njikoka Local Government area in the State with landmass of approximately 9.2 square kilometer and it is bordered in the North by Abba, Ukpo, Enugwu-agidi towns; in the East by Enugwu-ukwu town; and in the West by Umunnachi and Ifitedunu Towns, with no officially documented 
estimated population available. However, the population could be said to be dense. The economy of the area is mainly based on commerce and trade with a non-estimated number of patent medicine shops against three pharmacies.

\section{Study design}

This was an interventional study among patients from 18 years of age using a one group pre-post design. Information of the study was given by the researcher to patients who visited the pharmacy with history of asthma, evidence of having asthma disorder and seeking for help, or trying to fill a prescription of asthma medication(s).

\section{Inclusion criteria}

- $\quad$ Adult (male or female) from 18 years of age.

- Being treated for asthma for 12 months and above.

\section{Exclusion criteria}

- History of recurring lower respiratory tract that is being treated with antibiotics more than three times in the past twelve months.

- Known allergy to the components of the study product(s).

- Issue of illiteracy, or inability to speak, read, and write English language and unable to arrange for a translator themselves.

- Psychiatric disorder.

\section{Ethical Consideration}

A study code was used for the purpose of data analysis in other to ensure confidentiality of information. Ethical clearance was obtained from Chukwuemeka Odumegwu Ojukwu University Teaching Hospital, Awka Ethics Committee (Ref:COOUTH/CMAC/Eth.App./0034). Permission to undergo the study in the pharmacy was obtained from the management. Patients were made aware that participation was voluntary and they have the right to refuse or discontinue participation for any reason without penalty if he/she wishes, and the investigator can terminate a subjects' participation if the subject met an exclusion criterion, either by deliberately providing false information or not following the study procedure. 


\section{Data collection}

The pre- and post- test design was used with the subjects serving as their own control. The pretest contains two set questionnaire (sections A and B) designed for the study. Section A had the content that measured the factual information on the subjects' demographics which included the subject's age, sex, educational level, occupation; while section B contained: (i) 24-item questions on asthma knowledge, each with options of "true" or "false" in 5 domains - pathophysiology, symptoms/severity, medication and prevention, (ii) 8-item questions on the adherence to asthma medication use with responses on "yes" or "no" options, (iii) 15-item questions on the extent of asthma-related quality of life, with each question on a 7 point scale within 4 domains : Symptoms, emotional, environment stimuli, activity limitation, (iv) 7-item questions on perceived control of asthma with responses on option of answers that best describe the perception, (v) 5 steps criteria inhaler technique with standardized checklist specific to MDI (Metered dose inhaler) device that indicated "correct" and "incorrect" answers in each step.

Eligible subjects were invited to participate after they gave informed consent to be interviewed. Each subject answered the pretest questions before a 2-day individualized comprehensive education was instituted.

Day one included: (i) the pharmacist interaction with the patients in other to identify their area of concern, their beliefs and where they lack understanding of asthma disease; and was immediately addressed, (ii) education on asthma disease, signs and symptoms, (iii) education on asthma triggers exposure and warning signs. Day two included: (i) education on certain preventive measures for asthma trigger exposure and acute attacks for self-monitoring, (ii) education on the importance of drug use and adherence to medication use, (iii) education on inhaler technique use and demonstration of the use of inhaler device.

After the education, each subject was left to self-manage his/her asthma for the next two weeks and again invited following the elapse of the two weeks to fill a posttest questionnaire in other to reassess their knowledge of asthma, asthma-related quality of life, adherence to asthma medication use, perceived control of asthma, and inhaler technique; using a post test questionnaire. The subjects were not informed previously that they will be filling any other questionnaire. The posttest questionnaire omitted the first section (section A) of the questionnaire but the subsequent layouts were the same.

\section{Data analysis}

Data was collected, coded and entered into MS Office excel spreadsheet and statistical analysis were carried out using Statistical Package for Social Sciences (SPSS) for Windows version 23. McNemar test was used to test the statistical difference in the proportion of correct responses in pre-test and post-test of each item. 
The subjects' asthma knowledge ability was assessed using "true" or "false" categories Adherence to medication use by the subjects were assessed using a "yes" or "no" categories. The inhaler technique was assessed with scores given as " 1 " for correct answer and " 0 " for incorrect answer. The significant difference of the correct responses of the pre and post of each of the above measurements were all assessed using Mcnemar test. The subjects' responses to questions that assessed asthma-related quality of life were elicited using 7-point Likert scale (All of the time, most of the time, a good bit of time, some of the time, a little of the time, hardly any time, none of the time) on eleven questions and 7-point Likert scale (Totally limited, extremely limited, very limited, moderate limitation, some limitation, a little limitation, not at all limited).In the data analysis, the 7-point scale was collapsed into two categories: (1) Impaired (All of the time, most of the time, a good bit of time, some of the time) for the eleven questions and (totally limited, extremely limited, very limited, moderate limitation) for the remaining five questions, and (2) Not impaired (a little of the time, hardly any time, none of the time) for the eleven questions and (some limitation, a little limitation, not all limited) for the remaining four questions. Thereafter, Mcnemar test was used to test the difference in positive responses before and after the educational intervention in the subjects' asthma-related quality of life. P-values $<0.05$ were considered statistically significant.

The subjects' perceived control of asthma was assessed by the subjects' responses to questions that range from "no", "moderate", "extreme/severe". Their perception was categorized into two categories: (1) Control ("No" options) and (2) Uncontrolled ("moderate", "extreme/severe" options). Similar to above measurements, Mcnemar test was also used to test the statistical differences of their correct responses.

\section{Results}

Among the 26 subjects that met the inclusion criteria and gave consent for participation in the education program, 21 subjects $(81 \%)$ completed the program. Upon various attempts made to ensure that all the subjects completed the study which included phone calls to the subjects, sent reminder text messages on various occasions to them, and assurance that adequate incentives will be provided to them; a total of 5 subjects (19\%) defaulted from the study completion. The major reasons for the default were: No time because of the nature of their work, long distance of their homes/offices from the pharmacy, unexpected/unplanned travel. 2 (40\%) subjects gave reasons for no time, $1(20 \%)$ subject said that his home was far away from the pharmacy, while 2 (40\%) said that they made unplanned travel.

The demographic characteristics of the respondents included; gender, age, educational attainment, and occupation. Out of the total of 21 respondents who successfully completed the study, 12 (57.1\%) were males, while 9 (42.9\%) were females. Majority of the respondents who participated were aged between 38 and 47 years of age. However, all participants had formal education with 3 (14.3 
$\%)$ at primary, $8(38.1 \%)$ at secondary and $10(47.6 \%)$ at tertiary level. Majority, $10(47.6 \%)$ were self-employed; very few, $2(9.5$ $\%$ ) were retired; while 4(19.0\%) were unemployed and 5(23.6\%) were public/civil servants (Table 1).

Table 1: Demographic characteristic of the respondents $(n=21)$

\section{Characteristics}

Age (years)

$$
18-27
$$

$58-67$

$67-77$

\section{Frequency}

$(\%)$

$12(57.1)$

$9(42.9)$

3

5

6

3

3

Level of Education

$\begin{array}{lc}\text { Primary } & 3(14.3) \\ \text { Secondary } & 8(38.1) \\ \text { Tertiary } & 10(47.6)\end{array}$

Occupation

$\begin{array}{ll}\text { Unemployed } & 4(19.0) \\ \text { Self-employed } & 10(47.6) \\ \text { Public/civil servant } & 5(23.8) \\ \text { Retiree } & 2(9.5)\end{array}$

Table 2 presents the results of the correct responses to the questions on the impact of the education on asthma patients' knowledge. Prior to the educational intervention, almost all the subjects had prior knowledge that: (i) people with asthma can usually control their symptoms by taking medicine and avoiding things that make their asthma worse, (ii) untreated asthma can cause death, (iii) you should wait until symptoms are really bad before you use a quick relief medication like ventolin, (iv) to use an asthma inhaler correctly, you need to breathe in as you press down on the inhaler, (v) it does not bother your asthma when people smoke cigarettes around you, (vi) your bedroom is the most important room to keep free from dust and animal feathers, (vii) carpets that smell moldy can trigger asthma. However, virtually all the subjects do not have prior knowledge that: (i) the purpose of steroid medication is to stop asthma attack when it occurs, (ii) people with asthma do not need to take medicine if the feel normal, (iii) it may take 1-4 weeks 
to notice improvement in your breathing when you start using inhaled steroid medication, (iv) it is okay to take inhaled steroid medication only when you notice wheezing.

However, there was noticeable significant improvements after the intervention, on twelve items that included the following questions: (i) frequent coughing can be a symptom of asthma, (ii) people with asthma have swollen and inflamed airways even when they feel normal, (iii) asthma can be completely cured, (iv) people with asthma should avoid exercise, (v) the purpose of steroid inhalers is to stop an asthma attack when it occurs, (vi) people with asthma do not need to take medicine if they feel normal, (vii) it may take 1-4 weeks to notice improvement in your breathing when you start using inhaled steroid medication,(viii) it is okay to take inhaled steroid medication only when you notice wheezing, (ix) you should wait one minute between puffs of your quick relief medication(ventolin), (x) getting rid of cockroaches in your house may help your asthma, (xi) covering pillows and mattresses with plastic covers can trigger asthma, (xii) steroid inhalers will relieve asthma attack in 20 minutes.

Table 2: Impact of education on patient's knowledge of asthma.

\begin{tabular}{|c|c|c|c|c|c|}
\hline & Item Questions & $\begin{array}{l}\text { Pre } \\
\% \text { of correct } \\
\text { response }\end{array}$ & $\begin{array}{l}\text { Post } \\
\% \text { of correct } \\
\text { response }\end{array}$ & $\begin{array}{l}\text { McNemar Test } \\
\text { P-value } \\
(\alpha=0.05)\end{array}$ & Remarks* \\
\hline 1 & $\begin{array}{l}\text { Frequent coughing can be a symptom } \\
\text { of asthma. }\end{array}$ & $14(66.7 \%)$ & $21(100 \%)$ & 0.016 & $\mathbf{S}$ \\
\hline 2 & $\begin{array}{l}\text { People with asthma have swollen and } \\
\text { inflamed airways even when they } \\
\text { feel normal. }\end{array}$ & $8(38.1 \%)$ & $19(90.5 \%)$ & $<0.001$ & $\mathbf{S}$ \\
\hline 3 & Untreated asthma can cause death. & $16(76.2 \%)$ & $21(100 \%)$ & 0.063 & NS \\
\hline 4 & $\begin{array}{l}\text { People with asthma can usually } \\
\text { control their symptoms by taking } \\
\text { medicine and avoiding things that } \\
\text { make their asthma worse. }\end{array}$ & $20(95.2 \%)$ & $21(100 \%)$ & 1.00 & NS \\
\hline 5 & Untreated asthma can cause death. & $20(95.2 \%)$ & $21(100 \%)$ & 1.00 & NS \\
\hline 6 & Asthma can be completely cured. & $7(33.3 \%)$ & $14(66.7 \%)$ & 0.016 & $\mathbf{S}$ \\
\hline 7 & $\begin{array}{l}\text { People with asthma should avoid } \\
\text { exercise. }\end{array}$ & $8(38.1 \%)$ & $15(71.4 \%)$ & 0.016 & $\mathbf{S}$ \\
\hline 8 & $\begin{array}{l}\text { The purpose of steroid medication } \\
\text { inhalers is to stop an asthma attack } \\
\text { when it occurs. }\end{array}$ & $1(4.8 \%)$ & $15(71.4 \%)$ & $<0.001$ & $\mathbf{S}$ \\
\hline
\end{tabular}




\begin{tabular}{|c|c|c|c|c|c|}
\hline 9 & $\begin{array}{l}\text { People with asthma do not need to } \\
\text { take medicine if they feel normal. }\end{array}$ & $1(4.8 \%)$ & $9(42.9 \%)$ & 0.008 & $\mathbf{S}$ \\
\hline 10 & $\begin{array}{l}\text { Quick relief medication such as } \\
\text { Ventolin should always be taken } \\
\text { every day. }\end{array}$ & $14(66.7 \%)$ & $14(65.7 \%)$ & 1.000 & NS \\
\hline 11 & $\begin{array}{l}\text { You should wait until your } \\
\text { symptoms are really bad before you } \\
\text { use a quick relief medication such as } \\
\text { Ventolin. }\end{array}$ & $19(90.5 \%)$ & $19(90.5 \%)$ & 1.000 & NS \\
\hline 12 & $\begin{array}{l}\text { It may take } 1-4 \text { weeks to notice } \\
\text { improvement in your breathing when } \\
\text { you start using inhaled steroid } \\
\text { medication. }\end{array}$ & $0(0.0 \%)$ & $21(100 \%)$ & $<0.001$ & $\mathbf{S}$ \\
\hline 13 & $\begin{array}{l}\text { It is okay to take inhaled steroid } \\
\text { medication only when you notice } \\
\text { yourself wheezing. }\end{array}$ & $1(4.8 \%)$ & $13(61.9 \%)$ & $<0.001$ & $\mathbf{S}$ \\
\hline 14 & $\begin{array}{l}\text { To use an asthma inhaler correctly, } \\
\text { you need to breathe in as you press } \\
\text { down on the inhaler. }\end{array}$ & $18(85.7 \%)$ & $21(100 \%)$ & 0.250 & $\mathrm{NS}$ \\
\hline 15 & $\begin{array}{l}\text { You should hold your breath for } 10 \\
\text { seconds after each puff of your } \\
\text { inhaler. }\end{array}$ & $16(76.2 \%)$ & $20(95.2 \%)$ & 0.125 & NS \\
\hline 16 & $\begin{array}{l}\text { You should wait about one minute } \\
\text { between puffs of your quick relief } \\
\text { medication (Ventolin). }\end{array}$ & $8(38.1 \%)$ & $18(85.7 \%)$ & 0.002 & $\mathbf{S}$ \\
\hline 17 & $\begin{array}{l}\text { It does not bother your asthma when } \\
\text { people smoke cigarettes around you. }\end{array}$ & $18(85.7 \%)$ & $16(76.2 \%)$ & 0.50 & NS \\
\hline 18 & $\begin{array}{l}\text { Your bedroom is the most important } \\
\text { room to keep free of dust and animal } \\
\text { feathers. }\end{array}$ & $18(85.7 \%)$ & $21(100 \%)$ & 0.250 & NS \\
\hline 19 & $\begin{array}{l}\text { Getting rid of cockroaches in your } \\
\text { house may help your asthma. }\end{array}$ & $10(47.6 \%)$ & $20(95.2 \%)$ & 0.004 & $\mathbf{S}$ \\
\hline 20 & $\begin{array}{l}\text { Keeping your bedroom windows } \\
\text { open at night will help prevent } \\
\text { asthma symptoms. }\end{array}$ & $11(52.4 \%)$ & $13(61.9 \%)$ & 0.50 & NS \\
\hline 21 & $\begin{array}{l}\text { Carpets that smell moldy can trigger } \\
\text { asthma. }\end{array}$ & $18(85.7 \%)$ & $21(100 \%)$ & 0.250 & NS \\
\hline 22 & $\begin{array}{l}\text { Covering pillows and mattresses } \\
\text { with plastic covers can trigger } \\
\text { asthma. }\end{array}$ & $13(61.9 \%)$ & $20(95.2 \%)$ & 0.016 & $\mathbf{S}$ \\
\hline 23 & $\begin{array}{l}\text { Steroid inhalers will relieve an } \\
\text { asthma attack within } 20 \text { minutes. }\end{array}$ & $4(19.0 \%)$ & $16(76.2 \%)$ & $<0.001$ & $\mathbf{S}$ \\
\hline 24 & $\begin{array}{l}\text { Taking an antibiotic will help most } \\
\text { bad asthma attacks. }\end{array}$ & $16(76.2 \%)$ & $16(76.2 \%)$ & 1.000 & $\mathrm{NS}$ \\
\hline
\end{tabular}

$* \mathrm{~S}=$ significant, $\mathrm{NS}=$ not significant. 
Table 3: Impact of education on subjects' adherence.

\begin{tabular}{|c|c|c|c|c|c|}
\hline & Item Questions & $\begin{array}{l}\text { Pre } \\
\% \text { of those } \\
\text { that adhered } \\
\text { to } \\
\text { medication } \\
\text { use }\end{array}$ & $\begin{array}{l}\text { Post } \\
\% \text { of those } \\
\text { that } \\
\text { adhered } \\
\text { to } \\
\text { medication } \\
\text { use }\end{array}$ & $\begin{array}{l}\text { McNemar } \\
\text { Test } \\
\text { P-value }\end{array}$ & Remarks* \\
\hline 1 & $\begin{array}{l}\text { Do you sometimes forget to take your } \\
\text { asthma drugs? }\end{array}$ & $7(33.3 \%)$ & $16(76.2 \%)$ & 0.004 & $\mathbf{S}$ \\
\hline 2 & $\begin{array}{l}\text { People sometimes miss taking their } \\
\text { drugs for reasons other than forgetting. } \\
\text { Thinking over past } 2 \text { weeks, were there } \\
\text { any days when you did not take your } \\
\text { drug? }\end{array}$ & $2(9.5 \%)$ & $17(81.0 \%)$ & $<0.001$ & $\mathbf{S}$ \\
\hline 3 & $\begin{array}{l}\text { Have you ever cut back or stopped } \\
\text { taking your drug without telling your } \\
\text { doctor (or health provider) because you } \\
\text { felt worse when you took it? }\end{array}$ & $14(66.7 \%)$ & $19(90.5 \%)$ & 0.063 & NS \\
\hline 4 & $\begin{array}{l}\text { When you travel or leave home, do you } \\
\text { sometimes forget to bring your drug? }\end{array}$ & $16(76.2 \%)$ & $20(95.2 \%)$ & 0.125 & NS \\
\hline 5 & Did you take your drug yesterday? & $10(47.6 \%)$ & $19(90.5 \%)$ & 0.004 & $\mathbf{S}$ \\
\hline 6 & $\begin{array}{l}\text { When you feel like your symptoms are } \\
\text { under control, do you sometimes stop } \\
\text { taking your drugs? }\end{array}$ & $1(4.8 \%)$ & $16(76.2 \%)$ & $<0.001$ & $\mathbf{S}$ \\
\hline 7 & $\begin{array}{l}\text { Taking drug every day is a real } \\
\text { inconvenience for some people. Do you } \\
\text { ever feel hassled about sticking to your } \\
\text { treatment plan? }\end{array}$ & $4(19.0 \%)$ & $13(61.9 \%)$ & $<0.001$ & $\mathbf{S}$ \\
\hline 8 & $\begin{array}{l}\text { How often do you have difficulty } \\
\text { remembering to take all your drugs? }\end{array}$ & $6(28.6 \%)$ & $15(71.4 \%)$ & 0.004 & $\mathbf{S}$ \\
\hline
\end{tabular}

$* \mathrm{~S}=$ significant, $\mathrm{NS}=$ not significant. 
Table 4: impact of education on patients' asthma-related quality of life.

\begin{tabular}{|c|c|c|c|c|c|}
\hline & Item Questions & $\begin{array}{l}\text { Pre } \\
\% \quad \text { Positive } \\
\text { response }\end{array}$ & $\begin{array}{l}\text { Post } \\
\% \text { positive } \\
\text { response }\end{array}$ & $\begin{array}{l}\text { McNemar } \\
\text { Test } \\
\text { P-value } \\
(\alpha=0.05)\end{array}$ & Remarks* \\
\hline 1 & $\begin{array}{l}\text { Feel SHORT OF BREATH as a result of } \\
\text { your asthma? }\end{array}$ & $14(66.7 \%)$ & $18(85.7 \%)$ & 0.125 & NS \\
\hline 2 & $\begin{array}{l}\text { Feel bothered by or have to avoid dust in the } \\
\text { environment? }\end{array}$ & $9(42.9 \%)$ & $12(57.1 \%)$ & 0.250 & NS \\
\hline 3 & Feel frustrated as a result of your asthma? & $13(61.9 \%)$ & $18(85.7 \%)$ & 0.063 & NS \\
\hline 4 & Feel bothered by coughing? & $11(52.4 \%)$ & $20(95.2 \%)$ & 0.004 & $\mathbf{S}$ \\
\hline 5 & $\begin{array}{l}\text { Feel afraid of not having your asthma } \\
\text { medication available? }\end{array}$ & $3(14.3 \%)$ & $7(33.3 \%)$ & 0.125 & NS \\
\hline 6 & $\begin{array}{l}\text { Experience a feeling of chest tightness or } \\
\text { chest heaviness }\end{array}$ & $12(57.1 \%)$ & $19(90.5 \%)$ & 0.016 & $\mathbf{S}$ \\
\hline 7 & $\begin{array}{l}\text { Feel bothered by or have to avoid cigarette } \\
\text { smoke in the environment? }\end{array}$ & $6(28.6 \%)$ & $8(38.1 \%)$ & 0.50 & NS \\
\hline 8 & $\begin{array}{l}\text { Have difficulty in getting a good night sleep } \\
\text { as a result of your asthma. }\end{array}$ & $12(57.1 \%)$ & $18(85.7 \%)$ & 0.031 & $\mathbf{S}$ \\
\hline 9 & Feel concerned about having asthma? & $11(52.4 \%)$ & $16(76.2 \%)$ & 0.063 & NS \\
\hline 10 & Experience a wheeze in your chest? & $15(71.4 \%)$ & $14(66.7 \%)$ & 1.000 & NS \\
\hline 11 & $\begin{array}{l}\text { Feel bothered by or having to avoid going } \\
\text { outside because of weather or air pollution? }\end{array}$ & $7(33.3 \%)$ & $12(57.1 \%)$ & 0.063 & NS \\
\hline 12 & $\begin{array}{l}\text { Strenuous activities (such as hurrying, } \\
\text { exercising running up stairs, sports) }\end{array}$ & $12(57.1 .0 \%)$ & $20(95.2 \%)$ & 0.008 & $\mathbf{S}$ \\
\hline 13 & $\begin{array}{l}\text { Moderate activities (such as walking, house } \\
\text { work, gardening, shopping, climbing stairs) }\end{array}$ & $13(61.9 \%)$ & $20(95.2 \%)$ & 0.016 & $\mathbf{S}$ \\
\hline 14 & $\begin{array}{l}\text { social activities ( such as talking, playing } \\
\text { with pets/children, visiting friends/relatives }\end{array}$ & $19(90.5 \%)$ & $20(95.2 \%)$ & 1.000 & NS \\
\hline 15 & $\begin{array}{l}\text { Work-related activities (task you have to do } \\
\text { at work) }\end{array}$ & $19(90.5 \%)$ & $18(85.7 \%)$ & 1.000 & NS \\
\hline
\end{tabular}

$* \mathrm{~S}=$ significant, $\mathrm{NS}=$ not significant.

Table 5: Summary of result on perceived control of asthma 


\begin{tabular}{|l|l|l|l|l|l|}
\hline & Item Questions & $\begin{array}{l}\text { Pre } \\
\% \\
\text { positive } \\
\text { response }\end{array}$ & $\begin{array}{l}\text { Post } \\
\% \text { of positive } \\
\text { response }\end{array}$ & $\begin{array}{l}\text { McNemar } \\
\text { Pest } \\
(\alpha=0.05)\end{array}$ & Remarks* \\
\hline 1 & $\begin{array}{l}\text { How much does asthma illness affect } \\
\text { your life? }\end{array}$ & $3(14.3 \%)$ & $17(81.0 \%)$ & $<0.001$ & S \\
\hline 2 & $\begin{array}{l}\text { How much control do you feel you have } \\
\text { over illness? }\end{array}$ & $12(57.1 \%)$ & $14(66.7 \%)$ & 0.500 & NS \\
\hline 3 & $\begin{array}{l}\text { How much do you think your treatment } \\
\text { can help your illness? }\end{array}$ & $11(52.4 \%)$ & $18(85.7 \%)$ & 0.016 & $\mathbf{S}$ \\
\hline 4 & $\begin{array}{l}\text { How much do you experience } \\
\text { symptoms of asthma illness? }\end{array}$ & $2(9.5 \%)$ & $14(66.7 \%)$ & $<0.001$ & $\mathbf{S}$ \\
\hline 5 & $\begin{array}{l}\text { How concerned are you about your } \\
\text { illness? }\end{array}$ & $2(9.5 \%)$ & $16(76.2 \%)$ & $<0.001$ & $\mathbf{S}$ \\
\hline 6 & $\begin{array}{l}\text { How do you feel you understand your } \\
\text { illness? }\end{array}$ & $8(38.1 \%)$ & $16(76.2 \%)$ & 0.008 & $\mathbf{S}$ \\
\hline 7 & $\begin{array}{l}\text { How often does your illness affect you } \\
\text { emotionally? }\end{array}$ & $5(23.8 \%)$ & $9(42.9 \%)$ & 0.031 & $\mathbf{S}$ \\
\hline
\end{tabular}

$* \mathrm{~S}=$ significant, $\mathrm{NS}=$ not significant.

Table 6: Summary of inhaler device assessment tool

\begin{tabular}{|l|l|l|l|l|l|}
\hline & Item Questions & $\begin{array}{l}\text { Pre of correct } \\
\% \text { of } \\
\text { demonstration } \\
\text { demonstration } \\
\text { dect }\end{array}$ & $\begin{array}{l}\text { Mcst } \\
\text { P-value } \\
(\alpha=0.05)\end{array}$ & Remarks* \\
\hline 1 & Remove cap. & $21(100 \%)$ & $21(100 \%)$ & 1.000 & NS \\
\hline 2 & Correctly primes device. & $8(38.1 \%)$ & $17(81.0 \%)$ & 0.004 & S \\
\hline 3 & Exhales & $2(9.5 \%)$ & $15(71.4 \%)$ & $<0.001$ & S \\
\hline 4 & Inhales appropriately for device. & $8(38.1 \%)$ & $14(65.7 \%)$ & 0.031 & S \\
\hline 5 & Holds breath. & $13(61.9 \%)$ & $19(90.5 \%)$ & 0.031 & S \\
\hline
\end{tabular}

*S=significant, $\mathrm{NS}=$ not significant. 
Table 7 - Summary of the overall index of the impact of asthma education on each measuring tool

\begin{tabular}{|l|l|l|l|l|c|}
\hline S/N & Impact of asthma education & Pre & Frequency $(\%)$ & $\begin{array}{l}\text { Post } \\
\text { Frequency } \\
\%)\end{array}$ & $\begin{array}{l}\text { McNemar } \\
(\alpha=0.05)\end{array}$ \\
\hline 1 & Patients' asthma knowledge. & $259(53.6 \%)$ & $402(83.2 \%)$ & $<0.001$ & Semarks* \\
\hline 2 & Subjects' adherence & $60(35.7 \%)$ & $135(80.4 \%)$ & $<0.001$ & S \\
\hline 3 & Asthma-related quality of life. & $158(57.9 \%)$ & $214(78.4 \%)$ & $<0.001$ & S \\
\hline 4 & Perceived control of asthma. & $43(29.3 \%)$ & $104(70.7 \%)$ & $<0.001$ & S \\
\hline 5 & Inhaler technique & & $52(49.5 \%)$ & $86(81.9 \%)$ & $<0.001$ \\
\hline
\end{tabular}

$* \mathrm{~S}=$ significant, $\mathrm{NS}=$ not significant.

Table 3 provides the results of the responses before and after the intervention on subjects' adherence to medication use. More than half of the respondents exhibited high adherence capacity prior to the intervention by their responses on each of the following questions: (i) Have you ever cut back or stopped taking your drug without telling your doctor (or health provider) because you felt worse when you took it?, (ii) when you travel or leave home, do you sometimes forget to bring your drugs?. Nevertheless, there was a drastic improvement in adherence level after the educational intervention on the questions on: (i) If you sometimes forget to take your asthma drugs, (ii) If there were any days when you did not take your drug over past 2 weeks, (iii) If you stop taking your drugs when you feel your symptoms are under control, (iv) If you feel hassled about sticking to your treatment plan.

Table 4 shows the results of the responses on the questions on asthma-related quality of life before and after the education intervention. Few participants do not show that they feel : (i) Afraid of not having their medications available, (ii) bothered by or have to avoid cigarette smoke in the environment, (iii) bothered by or having to avoid going outside because of the weather; before and after the intervention. On the other hand, majority of the participants show positive responses in social and work-related activities before and after the intervention. While there was reasonable improvements in the responses on the patients': feeling of chest tightness or heaviness; feeling bothered by coughing; having difficulty in getting a good night sleep; strenuous activities; moderate activities; after the intervention. 
Table 5 describes the subjects' response to the questions concerning their degree of perception of control that is most appropriate to them before and after intervention. Very few gave positive responses in the questions on the extent: (i) asthma illness affects their life, (ii) they experience symptoms of asthma illness, (iii) they are concerned about their illness; before the intervention. Moreover, the subjects showed improvements on their perceptions that: asthma illness does not affect their life; that they do not experience symptoms of asthma illness; they are not concerned about their asthma illness; after the intervention.

Table 6 shows the correct responses on subjects' technique on the use of inhaler before and after intervention. All the subjects correctly removed inhaler cap, before and after the intervention. Before the intervention, very few (2) persons could exhale after priming, while slightly above half of the number of participants (13 persons) demonstrated that they could hold breath. However, there were improvements in all the steps after the intervention.

On the whole, the summary of the overall index of the impact of asthma education on each measuring tool before and after the education is presented in table 7. The overall index of the impact of the educational intervention can be summarized as follows: (i) The overall asthma knowledge correct responses was $53.6 \%$ before the intervention and $83.2 \%$ after the intervention, (ii) adherence to medication use correct responses for the participants in all the items had $35.7 \%$ before the intervention, but after the intervention the adherence abilities of the participants increased to $80.4 \%$, (iii) The response of good quality of life was presented in $57.9 \%$ of the subjects across all the items before the intervention; but after the intervention, $78.4 \%$ showed correct response across all the items, (iv) the overall perception of control increased from positive response in $29.3 \%$ of the participants before the intervention, to $70.7 \%$ of the participants after the intervention, (v) correct response was given by $49.5 \%$ of the participants across all the items in inhaler technique before the intervention, while the response increased to $81.9 \%$ after the intervention. 
Figure 1 - Bar chart of the summary of the pre-test and post-test of overall items of the measuring tools

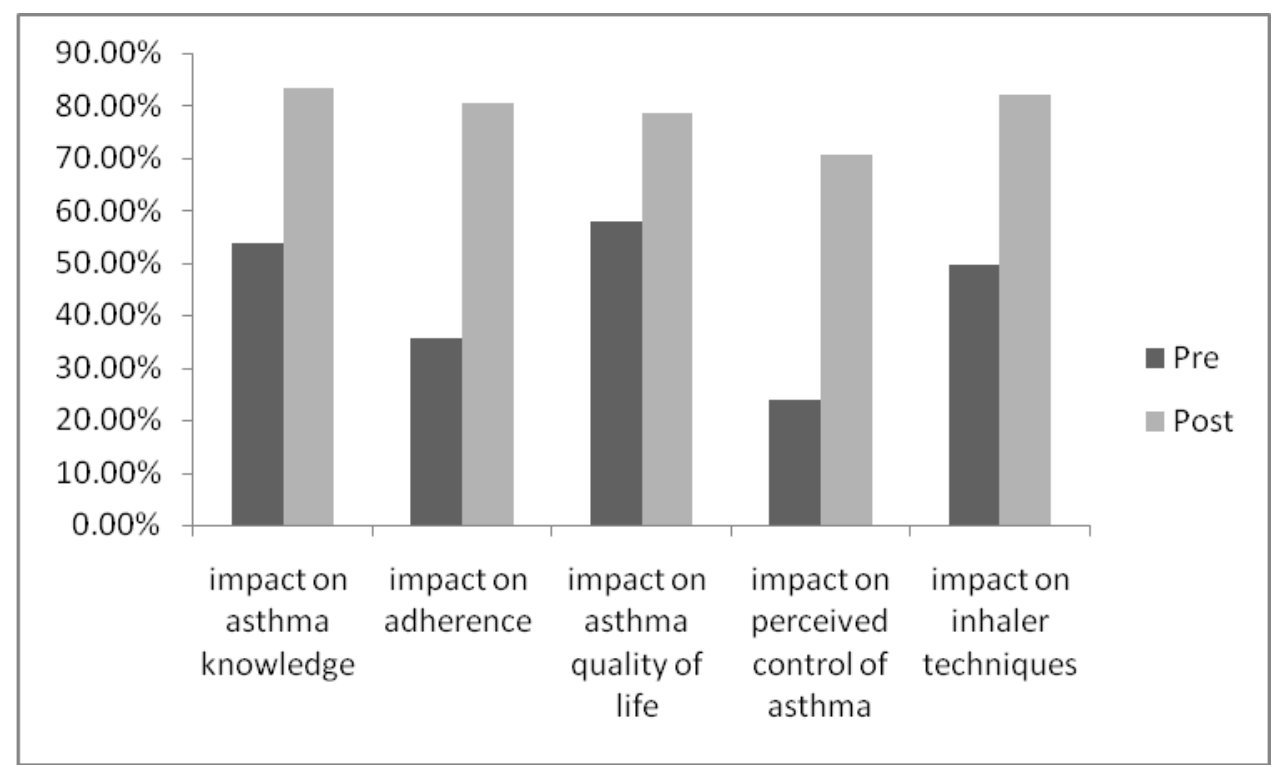

\section{Discussion}

The response rate of those that consented to participate can be said to be impressive, about $81 \%$. Several factors may be responsible for the high response rate and may include; a welcoming environment created where interview/educational program was conducted in an area that affords privacy, and the simple English language used in the questionnaire. The findings generally showed significant improvements in patients' asthma knowledge, patients' adherence to medication use, inhaler technique, patients' asthma - related quality of life, and patients' perceived control of asthma; after the educational intervention in the three months study.

These results are consistent with those studies achieved by other pharmacy-based asthma care models ${ }^{(5,16,18,22)}$ using different community pharmacies with control and intervention groups. However, in this case a comprehensive education was performed by a pharmacist using a single community pharmacy with subjects serving as their own control.

\section{Asthma Knowledge}

Majority of the patients exhibited prior knowledge on asthma prevention and the need for medication compliance. This may be as a result of information from public awareness, information from healthcare providers or the participants' individual experience on the illness management. But virtually all the patients had no sufficient knowledge of inhaled corticosteroid, its use in asthma management, and the pathophysiology of asthma, prior to the intervention. Some studies have identified that healthcare providers rarely prescribe inhaled corticosteroids for asthma management and patients rarely use them even when it is prescribed, probably 
because of its cost or their experience of its non-immediate effect compared to the bronchodilators ${ }^{(8)}$. Due to these factors, the consequence is that the patients may not see the importance or its effect in asthma management ${ }^{(8)}$. But after the comprehensive education, it was found that there were marked improvements on subjects' knowledge on inhaled corticosteroids and their uses, pathophysiology of asthma and other domains in asthma knowledge. It implies that the asthma education given improved asthma patients' knowledge on self-management thereby improved the humanistic outcome.

\section{Subjects' adherence}

It was observed before the intervention, that only one patient indicated continuing medication when symptoms are under control, while two patients complied with medication use over the previous 2 weeks before the intervention. The finding is in line with various researches in developing countries which have consistently shown that inadequate education is one of the common barriers of poor adherence to controller medications ${ }^{(23)}$. Therefore, comprehensive education to the patients can improve adherence to controller treatment and its long - term benefits. After the education program, the number of patients that gave positive responses to adherence to medication use improved by more than half. This implies that the community pharmacist's role in educating the patients on the importance of adhering to medication use through education improved the clinical outcome.

\section{Asthma quality of Life}

Prior to the intervention, more than $50 \%$ but less than $70 \%$ of the participants indicated good asthma - related quality of life. This may imply that the group had mild to moderate asthma health status while greater than $30 \%$ have functional impairment before the educational program across all items. After the education program, there was a general improvement across all items since the number of those that indicated good quality of life increased to greater than $70 \%$ after the intervention. This implies that a comprehensive educational intervention from the community pharmacist on the patients concern and belief improved the symptoms, mood disturbances, prevention of environmental stimuli, and concerns about health; thereby improving the humanistic outcome. The result can be compared with studies that showed improved asthma treatment outcomes after educational intervention ${ }^{(16)}$.

\section{Inhaler technique}

Poor delivery of the medication result to poor outcome and can be described as poor inhaler technique which is one of the major contributing factors in poor asthma control ${ }^{(21)}$. The findings for inhaler device assessment showed significant improvement in all the steps and criteria on inhaler technique after the education. The overall index across all items before the education program shows that slightly less than $50 \%$ (49.5\%) of the participants had good knowledge of inhaler technique but the number increased to greater than $80 \%(81.9 \%)$ after the education program. The result implies that though the patients generally had average knowledge on the inhaler 
technique prior to the education, the education and training given by the community pharmacist minimized the errors commonly made by the patients and maximized the patients' inhaler technique. The result can be compared to other models used in assessing asthma patients' inhaler technique ${ }^{(18,22)}$.

\section{Perceived control of asthma}

The humanistic outcomes can be said to improve since in the perceived control of asthma; across all items, the patients' perception of control moved from $29.3 \%$ of the participants before the intervention to $70.7 \%$ of the participants. Less than half of the participants had good perception of asthma control prior the intervention but after the intervention, a noticeable improvement was seen. This finding can be compared to two earlier studies on asthma care and education in general ${ }^{(5,16)}$. It implies that the community pharmacist's education and counseling improved the patients' perception that their asthma was uncontrolled and not properly managed.

\section{Limitations}

There were some unavoidable limitations in the study although this research was diligently performed. The major drawback of the study was that since the assessment of the pre-test and post-test was conducted by a researcher, there may be certain degree of subjectivity. In other words, it would have been more objective if more researchers were involved. Second, the outcomes were achieved in 3 months; the time may not be enough since we do not know of the sustainability in a long term. Third, the community pharmacy used for the study may not represent an ideal pharmacy for such study. Fourth, there was no confirmation of asthma illness on the participants; this implies that some chronic obstructive pulmonary disease (COPD) patients and other chronic respiratory disease patients may have enrolled for the study. Finally, sample used for the study was small, only 21 subjects. They might not represent the majority of asthma sufferers to whom results can be generalized.

\section{Conclusion}

The study showed that with educational intervention in the community pharmacy, there were significant improvements on the patients' knowledge in asthma, patients' perceived control of asthma, patients' compliance to treatment regimen, patients' inhaler technique and patients' asthma-related quality of life. In other words, consistent education in the community pharmacy settings can increase self-management abilities, reduce emergency hospitalization, patients concern about asthma illness, morbidity and mortality rates. 


\section{Recommendations}

The findings of this study suggest that a well structured community pharmacy-based education program should be implemented into the community pharmacies workflow in Nigeria. Also, a mandatory continuing educational program on asthma management should be implemented to all community pharmacists practicing in Nigeria, to ensure consistency in utilizing their potentials. Finally, further research should be conducted in a large scale over a long time on asthma care programs in community pharmacies in Nigeria.

\section{REFERENCES}

1. Adeloye,D., Chan, K., Rudan, I., Campbell, H.(2013) An estimate of asthma prevalence in Africa: a systematic analysis. Croat Med J, 54:519-31.

2. Al-Jahdali, H., Ahmed, A., Al-Harbi, A., Khan, M., Baharoon, S., Bin-Sali, S., ..., Al-Mushen,S. (2013) Improper Inhaler technique is associated with poor asthma control and frequent emergency department visits. Allergy asthma clini immunol, $9(1): 8$

3. Al-Muhsen, S., Horanieh, N., Dulgom, S., Assiri, Z., Vazquez-Tello, A., Halwani, T., Al - Jahdali, H. (2015) Poor asthma education and medication compliance are associated with increased emergency department visits by asthmatic children. Ann thorac med 10(2) 123-131.Chronic lung diseases (abstract): chest 1034 (suppl); 289S.

4. Al - Zahrani, J., Ahmad, A., Al-Harbi, A., Khan, A., Al-Bader, B., Baharoon, S., ....., Al - Jahdali, H. ( 2015 ) Factors associated with poor asthma control in the outpatient clinic setting. Annal Thorac Med 10(2): $100-104$.

5. Armour, C., Bosnci-Anticevich, S., Brilliant, M., Burton, D., Emmerton, L., Krass, L., Bandana, S.,..... Stewart, K. (2007) Pharmacy asthma Care program improves outcomes for patient in the community. Thorax 62(6):496-502.

6. Baygul, A., Ozturk, A., Ozyigit, L., Keskin, H., Karakaya, G., Kalyoncu, F., Senocak, M. (2017) The reliability and validation of Turkish version of the asthma self management knowledge questionnaire. Turk Thorac J 18: 125-30.

7. Braido, F. (2013) Failure in asthma control: reasons and consequences. Scientifica http: // dx.doi.org/10.1155/2013/549252.

8. Chen - Yuan, C., Ait - Khaled, N. (2011) Essentials of asthma management. Global asthma report.

9. Davies, B., Danesco, E., Cicutto, L., Higuchi, K., McConnell, H., Edwards, N., MacPherson, A., Clarke, D. (2006). Nursing best practice guidelines evaluation user guide: inhaler device assessment tool for promoting asthma control in children. Nursing best practice research unit, University of Ottawa, Canada.pp.1-30. 
10. Etim, E. (2016) 100 million Nigerians may suffer from asthma in 2025.punch newspaper may 10.

11. Expert panel report 3: Guidelines for the diagnosis and management of asthma (2007) National heart, lung and blood institute (US).

12. Global Initiative for Asthma (1995) Global strategy for asthma management and prevention. Bethseda, MD. NIH Publication no. $95-365$

13. Juniper, E., Guyatt, G., Cox, F., Ferrie, P., King, D. (1999) Development and validation of the mini asthma quality of life questionnaire. Eur Respir J 14(1): 32-8.

14. Haahtela,T., Ellwood, O., Ait-Khaled, N.(2014) National asthma strategies. Global asthma report Pg 44-47.

15. Kelso, T., Self, T., Rumbark, M., Stephens, M., Garret, W., Arheat, K. (1995) Long-term therapeutic intervention in the ED: effect on outcomes in adult indigent minority asthmatics. Am J Emerg Med 13:632-7.

16. Larson, A., Ward, J., Ross, L., Whyatt, D., Weatherson, M., Landau, L. (2010) Impact of structured education and selfmanagement on rural asthma outcomes. Aust Fam Phys 39(3):141-4.

17. Mark, G., Neil, P., David, S., Innes, A. (2014) Global burden of disease due to asthma. The global report pg 16-20.

18. Mehuy, E., Van, B., De Bolle, L.,VanTongelen, I., Annemans, L., ... Bruselle, G. (2008) Effectiveness of pharmacist intervention for asthma control improvement. Eur respire J 31(4) 790-9.

19. Morisky, D., Green, L., Levine, D. (1986) Concurrent and predictive validity of a self-reported measure of medication adherence. Medicare 24:67-74.

20. Nduka, S., Anetoh, M., Amorha, K., Okechukwu, H., Okonta, M. (2016) Use of simulated patient approach to assess the community pharmacists knowledge of appropriate use of metered dose inhaler. Journal of basic and clinical pharmacy.

21. Onyedum, C., Ukwaja, K., Desalu, O., Ezeudo, C. (2013) Challenges in the management of bronchial asthma among adults in Nigeria : A systematic review. Ann Med Health Sci Resp 3: 324 - 9.

22. Prabhakaran, L., Lim, G., Absiheganadan, J., Chee, C., Choo, Y. (2006) Impact of an education programme on patients' knowledge, inhaler technique and compliance to treatment. Singapore Med J 47(3):225-231.

23. Sadatsafavi, M., FitzGerald, M. (2014) The economic burden of asthma. Global asthma report pg 36-38.

24. Tiffany, M., Alloaway, R., Self, T. (1992) Asthma patient education. Retrieved from https:// doi.org/10.1177/089719009200500405.

25. The World Health Organization's WHOQOL BREF quality of life assessment (2004) Psychometric properties and results of the international field trial. A report from the WHOQOL Group Quality of Life research 13: 299-310. 